\title{
Vitamin D Status and Vitamin D-Dependent Apoptosis in Obesity
}

\author{
Igor N. Sergeev
}

Department of Health and Nutritional Sciences, South Dakota State University, Brookings, SD 57007, USA; igor.sergeev@sdstate.edu

Received: 26 February 2020; Accepted: 7 May 2020; Published: 13 May 2020

\begin{abstract}
The role of vitamin D in obesity appears to be linked to vitamin D insufficient/deficient status. However, mechanistic understanding of the role of vitamin D in obesity is lacking. We have shown earlier that the vitamin $\mathrm{D}$ hormonal form, 1,25-dihydroxyvitamin $\mathrm{D}_{3}\left(1,25(\mathrm{OH})_{2} \mathrm{D}_{3}\right)$, induces cell death by apoptosis in mature adipocytes. This effect of the hormone is mediated by the cellular $\mathrm{Ca}^{2+}$ signaling pathway: a sustained increase of intracellular (cytosolic) $\mathrm{Ca}^{2+}$ concentration followed by activation of $\mathrm{Ca}^{2+}$-dependent initiators and effectors of apoptosis. In recent animal studies, we demonstrated that low vitamin D status is observed in diet-induced obesity (DIO). High intake of vitamin $\mathrm{D}_{3}$ in DIO decreased the weight of white adipose tissue and improved biomarkers related to adiposity and $\mathrm{Ca}^{2+}$ regulation. The anti-obesity effect of vitamin $\mathrm{D}\left(1,25(\mathrm{OH})_{2} \mathrm{D}_{3}\right)$ in DIO was determined by the induction of $\mathrm{Ca}^{2+}$-mediated apoptosis in mature adipocytes executed by $\mathrm{Ca}^{2+}$-dependent apoptotic proteases (calpains and caspases). Thus, a high intake of vitamin D in obesity increases vitamin D nutritional status and normalizes vitamin D hormonal status that is accompanied by the reduction of adiposity. Overall, our findings imply that vitamin D may contribute to the prevention of obesity and obesity-related diseases and that the mechanism of the anti-obesity effect of $1,25(\mathrm{OH})_{2} \mathrm{D}_{3}$ includes induction of $\mathrm{Ca}^{2+}$-mediated apoptosis in adipocytes.
\end{abstract}

Keywords: 1,25-dihydroxyvitamin $\mathrm{D}_{3}$; apoptosis; adipocytes; intracellular $\mathrm{Ca}^{2+}$; obesity; vitamin D status

\section{Introduction}

Vitamin D is considered important for maintaining good health and preventing disease, however, the causality of those claims has not been mechanistically or probabilistically substantiated [1-3]. Vitamin $\mathrm{D}_{3}$ is the precursor of a secosteroid hormone 1,25-dihydroxyvitamin $\mathrm{D}_{3}\left(1,25(\mathrm{OH})_{2} \mathrm{D}_{3}\right)$, which regulates a number of cellular functions, including the process of apoptotic cell death [4-8]. The mechanisms of hormonal effects of $1,25(\mathrm{OH})_{2} \mathrm{D}_{3}$ underlie its role in the regulation of cellular $\mathrm{Ca}^{2+}$ signaling, which, in turn, mediates a number of cellular responses, particularly $\mathrm{Ca}^{2+}$-mediated apoptosis [9-12].

Vitamin D deficiency and insufficiency (defined as a decreased concentration in blood of the transport form of this vitamin, 25-hydroxyvitamin D (25(OH)D)) appears to be associated with obesity [13]. The hormone $1,25(\mathrm{OH})_{2} \mathrm{D}_{3}$ plays a role in remodeling of adipose tissue via apoptotic $\mathrm{Ca}^{2+}$ signaling [14-16], and removal of mature adipocytes via $1,25(\mathrm{OH})_{2} \mathrm{D}_{3} / \mathrm{Ca}^{2+}$-mediated apoptosis may contribute to the maintenance of body weight and promotion of weight loss.

The purpose of this review is to discuss the potential link of vitamin D status to obesity and the role of $1,25(\mathrm{OH})_{2} \mathrm{D}_{3}$ in the regulation of adiposity, with emphasis on signaling pathways that involve vitamin D-dependent regulators, initiators, and effectors activated via $1,25(\mathrm{OH})_{2} \mathrm{D}_{3}$-induced cellular $\mathrm{Ca}^{2+}$ signaling. Understanding the role of vitamin D nutritional and hormonal status in obesity and mechanisms of $1,25(\mathrm{OH})_{2} \mathrm{D}_{3}$ in regulation of apoptosis in adipose tissue is important because it may 
influence the development of dietary recommendations for vitamin D and lead to the discovery of novel therapeutic and preventive modalities for this disease.

\section{Vitamin D Status in Health and Obesity}

Vitamin D status can be defined as sufficient, insufficient, or deficient. It depends on the level of exposure of unprotected skin to sun/UVB light and dietary/supplementary intake of this vitamin. The U.S. Institute of Medicine (IOM) [17,18], the Endocrine Society and the American Association of Clinical Endocrinologists [19], the European Food Safety Authority [20], and health regulatory agencies of several European countries [21,22] have established recommended vitamin D intake or defined vitamin D status (concentration of $25(\mathrm{OH}) \mathrm{D}$ in blood) as sufficient and deficient. Elevated and high vitamin D intake amounts (above the current upper-level intake of $4000 \mathrm{IU}$ per day as defined by the IOM) have been and are currently promoted as beneficial for maintaining optimal health and preventing numerous diseases $[3,19,23]$. A mechanistic approach can provide needed clarity in defining vitamin D status, particularly the importance of measuring $25(\mathrm{OH}) \mathrm{D}$ concentration in blood as an indicator of vitamin D sufficiency. I would provocatively argue that vitamin D, as a hormonal precursor, requires such an approach for establishing its dietary requirements and defining its nutritional status or-a somewhat heretical view-it is not possible to establish dietary requirements for, and optimal status of, vitamin $\mathrm{D}(25(\mathrm{OH}) \mathrm{D})$ based on currently used approaches.

The normal, physiological concentration of the active, hormonal form of vitamin $\mathrm{D}_{3}, 1,25(\mathrm{OH})_{2} \mathrm{D}_{3}$, in blood and target tissues of healthy adults is homeostatically regulated and maintained regardless of circulating concentration of its precursor, $25(\mathrm{OH}) \mathrm{D}_{3}[4,5,21]$. This implies that it is irrelevant (in healthy individuals under normal physiological and appropriate environmental conditions) how much of vitamin $\mathrm{D}_{3}$ or $25(\mathrm{OH}) \mathrm{D}_{3}$ is available for the biosynthesis of $1,25(\mathrm{OH})_{2} \mathrm{D}_{3}$ if it is sufficient/adequate for maintaining the circulating concentration of $1,25(\mathrm{OH})_{2} \mathrm{D}_{3}$ at the physiological ("normal") level. The amount of available substrate, $25(\mathrm{OH}) \mathrm{D}_{3}$, is not a limiting factor for the production of $1,25(\mathrm{OH})_{2} \mathrm{D}_{3}$ under those conditions. For example, it would mean that intake/production of $600 \mathrm{IU}$ vitamin D per day (the current recommendation), intake of $4000 \mathrm{IU}$ (the current upper-level intake of vitamin D per day), the concentration of $25(\mathrm{OH}) \mathrm{D}$ in blood $20 \mathrm{ng} / \mathrm{mL}$ (low "normal" level) or $100 \mathrm{ng} / \mathrm{mL}$ (the highest level observed with excessive sun exposure) are all "sufficient" for maintaining the circulating concentration of $1,25(\mathrm{OH})_{2} \mathrm{D}_{3}$ at the physiological level. The concentration of $1,25(\mathrm{OH})_{2} \mathrm{D}_{3}$ in blood is three orders of magnitude lower than the "normal" level of $25(\mathrm{OH}) \mathrm{D}_{3}$ (in picomolar vs. nanomolar range) and the life of $1,25(\mathrm{OH})_{2} \mathrm{D}_{3}$ in circulation is shorter than that of $25(\mathrm{OH}) \mathrm{D}_{3}[4,5,21]$, which, again, clearly indicates a "sufficient" substrate-product relationship in this enzymatic reaction. High (yet not toxic) levels of vitamin D intake or prolonged sun/UVB exposure can significantly increase $25(\mathrm{OH}) \mathrm{D}$ concentration in blood, which increases vitamin D nutritional status/reserves so that physiological functions of vitamin $\mathrm{D}$ can be adequately performed for several months. Extra-renal production of $1,25(\mathrm{OH})_{2} \mathrm{D}_{3}$ utilizes $25(\mathrm{OH}) \mathrm{D}_{3}$ in situ, but it does not appear to contribute to maintaining the circulating $1,25(\mathrm{OH})_{2} \mathrm{D}_{3}$ level and the possible involvement of such production in paracrine/autocrine regulation of cellular functions is not clear $[6,7]$.

An important point to note is that in the enzymatic reaction producing $1,25(\mathrm{OH})_{2} \mathrm{D}_{3}$, the substrate, $25(\mathrm{OH}) \mathrm{D}_{3}$, mechanistically functions not as a rate-limiting, but rather as an inhibitory substrate (i.e., high concentrations of $25(\mathrm{OH}) \mathrm{D}_{3}$ in the blood will inhibit production of $1,25(\mathrm{OH})_{2} \mathrm{D}_{3}$ in kidneys); moreover, the metabolism of $25(\mathrm{OH}) \mathrm{D}_{3}$ shifts toward 24,25 -dihydroxyvitamin $\mathrm{D}_{3}$ at high concentrations of this substrate $[4,21,24,25]$.

Thus, in the context discussed, it can be argued that establishing the optimal levels of vitamin D intake and the "normal" values of $25(\mathrm{OH}) \mathrm{D}$ concentration in the blood are not particularly relevant from a mechanistic perspective.

Biological responses to $1,25(\mathrm{OH})_{2} \mathrm{D}_{3}$ are determined by the concentration, spatial and temporal distribution, and the ligand- and DNA-binding activities of vitamin D receptors (VDRs) in the cell. VDRs at approximately $50 \%$ occupation level by its ligand $\left(1,25(\mathrm{OH})_{2} \mathrm{D}_{3}\right)$ mediate maximum 
genomic and non-genomic cellular responses, and this binding level is achieved at the physiological (picomolar) concentrations of $1,25(\mathrm{OH})_{2} \mathrm{D}_{3}[1,2,26,27]$. The mechanistic conclusion is that the circulating concentration of the hormone $1,25(\mathrm{OH})_{2} \mathrm{D}_{3}$ must be maintained at the precise, narrow-range level within a broad range of concentrations of $25(\mathrm{OH}) \mathrm{D}_{3}$, thus permitting $1,25(\mathrm{OH})_{2} \mathrm{D}_{3}$ to mediate, via VDRs, cellular responses and perform normally, in a highly adaptive and homeostatic fashion its physiological functions even at the "insufficient" vitamin D status (similar to the functioning of other steroid hormones).

It is also worth mentioning that that rickets and osteomalacia are observed when $25(\mathrm{OH}) \mathrm{D}$ is "undetectable" in blood (below $0.5-5 \mathrm{ng} / \mathrm{mL}$ depending on the assay) and that major physiological functions of $1,25(\mathrm{OH})_{2} \mathrm{D}_{3}$ (intestinal $\mathrm{Ca}^{2+}$ absorption and bone growth, mineralization, and remodeling) can be maintained at optimal level in healthy individuals at concentrations of $25(\mathrm{OH}) \mathrm{D}$ in the range of 10-20 ng/mL (probably, even lower levels can be sufficient because they will not limit the production of $\left.1,25(\mathrm{OH})_{2} \mathrm{D}_{3}\right)$. In this context, claims regarding widespread vitamin $\mathrm{D}$ "deficiency" and the benefits of measuring $25(\mathrm{OH}) \mathrm{D}$ routinely and/or in various populations should be considered with skepticism. The definition of vitamin D insufficiency as a 25(OH)D concentration in the range of 20-30 ng/mL [3,23] is not particularly relevant from the mechanistic and, probably, nutritional/health points of view.

The important rationale for increasing dietary vitamin D intake when skin exposure to sunlight is low (e.g., due to geographic location, time indoors, skin color, sunscreen use, etc.) and maintaining $25(\mathrm{OH}) \mathrm{D}$ concentration in the range of $30-60 \mathrm{ng} / \mathrm{mL}$ is the potential role of vitamin $\mathrm{D}$ in preventing certain diseases [1-3,23], but the mechanisms of those effects and their association with vitamin D status remain largely speculative. It is also important to emphasize that a sustained $25(\mathrm{OH}) \mathrm{D}$ concentration above 100-150 ng/mL can increase the risk of vitamin D toxicity. In the case of therapeutic effects of vitamin $\mathrm{D}$, pharmacological concentrations of the hormone, $1,25(\mathrm{OH})_{2} \mathrm{D}_{3}$, in blood and target tissues are required $[8,12,26,27]$, and those levels cannot be achieved with vitamin D supplementation or sunlight/UVB exposure due to the homeostatic regulation of $1,25(\mathrm{OH})_{2} \mathrm{D}_{3}$ production. Moreover, $1,25(\mathrm{OH})_{2} \mathrm{D}_{3}$ in pharmacological concentrations causes significant side effects (hypercalcemia, bone resorption, etc.), and evaluations (including clinical trials) of noncalcemic analogs of $1,25(\mathrm{OH})_{2} \mathrm{D}_{3}$ provided mixed or discouraging results $[8,12]$.

The vitamin D-dependent mechanisms in disease and the causal relationship between vitamin $\mathrm{D}$ status and disease (except vitamin D-deficient rickets/osteomalacia and inherited vitamin D receptor/vitamin D metabolism disorders) have yet to be identified, although an increased risk of some diseases (including obesity) has been linked to vitamin D deficiency and insufficiency $[1,2,6,13]$. Concurrently, disease states can alter vitamin D functioning, e.g., obesity may lower vitamin D status due to the accumulation and immobilization of vitamin D metabolites in adipose tissue and impaired conversion of vitamin D compounds in the liver and kidneys as well as affect the activity of vitamin D receptors [6,13].

The risk of acute and chronic vitamin D toxicity should not be underestimated. Examples of acute nutritional toxicity/death include consumption of vitamin $\mathrm{D}_{3}$ concentrate in vegetable oil (used on poultry farms) as cooking oil 25OHD concentration in blood of these people was 200-1000 ng/mL) and consumption of polar bear liver (vitamin D and A toxicity) [4,21]. Examples of chronic toxicity include calcification of soft tissues, particularly the aorta and kidneys [4,21]. To avoid toxicity, intake at levels of more than 4000 IU per day (the official IOM upper-level intake recommendation) or 5000-10,000 IU per day (by Rx) for prolonged periods of time (over several months) should be avoided and not recommended (due to increased risk of kidney stones, soft tissues (particularly, vascular) calcification, cardiovascular disease, coronary artery disease, etc.). In pediatric patients (recommendation of the American Academy of Pediatrics), the maximum dose of vitamin D is 50,000 IU one time per week, not for more than two months. Interestingly, even larger doses of vitamin D have been used for prophylaxis of rickets in certain populations in several European countries (e.g., a single dose of 300,000 IU) with no apparent side effects. However, it needs to be considered that infants and very old individuals do not have fully expressed/functional vitamin $\mathrm{D}$ hydroxylases and vitamin $\mathrm{D}$ 
receptors as well as a fully developed/expressed system for intestinal $\mathrm{Ca}^{2+}$ absorption (calbindin-D), therefore, a large vitamin D intake can be irrelevant in those cases. Furthermore, it is worth noting that the $25(\mathrm{OH}) \mathrm{D}$ concentration in human breast milk (including mothers with "normal" 25(OH)D concentration in their blood) is "very low" (it is not sufficient to meet the Adequate Intake (AI) of breastfed infants as defined by the IOM), possibly indicating low requirements for vitamin D in, or inability to utilize vitamin D by, infants. The skin of most terrestrial mammals is well protected from sun exposure, but they are not vitamin D deficient in the wild, even at high latitudes (and they do not get much vitamin $\mathrm{D}$ by licking their fur). Naturally vitamin D-deficient naked mole rats have undetectable levels of 25(OH)D [13] but are perfectly healthy and only express a unique-for-mammals social behavior (resembling that of social insects), extreme longevity (lifespan over 30 years), and are "naked" (either because of vitamin D deficiency or living underground). On the other hand, there is an interesting hypothesis that a mutation resulting in the light skin facilitated the migration of humans out of the tropics by allowing sufficient vitamin D production [13].

The controversial points made above emphasize that, in discussing vitamin D status in health and disease, it is critical to consider that the normal, physiological concentration of the active, hormonal form of vitamin $\mathrm{D}_{3}-1,25(\mathrm{OH})_{2} \mathrm{D}_{3}$-in the blood and target tissues of healthy adults is regulated and maintained within a broad range of concentrations of its precursor, $25(\mathrm{OH}) \mathrm{D}_{3}$. I do not claim that sufficient (yet to be appropriately defined as such) vitamin D status is not critically important for maintaining good health and preventing diseases but suggest that increasing vitamin D intake above the levels currently recommended by the IOM, probably, will not provide additional health benefits. Conversely, vitamin D status (25(OH)D concentration in blood) can serve as an excellent marker of good health [6], so that many of the variables that contribute to decreased 25(OH)D concentration (unhealthy dietary patterns, low level of physical activity, aging, dark skin) are also risk factors for the development of diseases, including obesity. Therefore, mechanistic studies and clinical intervention trails are critical for resolving the uncertainty regarding potential benefits of increasing vitamin $\mathrm{D}$ intake for maintaining good health and preventing disease.

\section{Vitamin D-Mediated Apoptosis and Obesity}

Apoptosis, a highly regulated form of cell death, is the main mechanism for controlling cell numbers in most tissues [11,28-37]. The remodeling of adipose tissue via apoptosis is critical for maintaining an appropriate number of adipocytes by eliminating mature, oversized cells and, thus, helping to sustain the normal adipose tissue and body mass. Obesity due to increased adipose tissue mass can result from an increase in adipocyte number (hyperplasia) and/or an increase in adipocyte size (hypertrophy) [13]. An adequate rate of adipocyte apoptosis may prevent the excessive accumulation of adipose tissue, whereas an increased rate of apoptosis will result in the loss of adipose tissue mass over time. It was established recently [13] that mature, differentiated adipocytes undergo apoptosis and are not as stable a cell type as previously thought. Thus, the induction of adipocyte apoptosis can be employed as a strategy for the prevention and treatment of obesity because removal of adipocytes via this mechanism will result in a reduction in body fat and a long-lasting maintenance of weight loss.

The hypothesis that vitamin $\mathrm{D}$ can be a determinant of obesity risk is plausible from a mechanistic perspective because $1,25(\mathrm{OH})_{2} \mathrm{D}_{3}$ regulates the fate of adipocytes via apoptosis $[1,2,6,10,14,37]$. The apoptotic effect of vitamin $\mathrm{D}$ in these cells is mediated by nuclear VDRs and the regulatory effects of $1,25(\mathrm{OH})_{2} \mathrm{D}_{3}$ in $\mathrm{Ca}^{2+}$ signaling (through voltage-insensitive $\mathrm{Ca}^{2+}$ channels linked to membrane VDRs) $[9,14,16]$. The possible in situ production of $1,25(\mathrm{OH})_{2} \mathrm{D}_{3}$ in adipocytes and other cells in adipose tissue (e.g., macrophages) should be also considered.

Cellular $\mathrm{Ca}^{2+}$ signaling in adipocytes is critical among the signaling pathways linked to obesity $[7,13,14]$, and this signaling is also a main target of the $\mathrm{Ca}^{2+}$ regulatory hormone $1,25(\mathrm{OH})_{2} \mathrm{D}_{3}[1,2,4]$. Intracellular $\mathrm{Ca}^{2+}$ signals can trigger apoptosis in various cell types, but $\mathrm{Ca}^{2+}$-dependent mediators involved in the downstream apoptotic signaling have not been conclusively identified. We $[7-10,12,29,30,32-37]$ and others $[11,31]$ have shown that an increase 
in concentration of intracellular (cytosolic) $\mathrm{Ca}^{2+}\left(\left[\mathrm{Ca}^{2+}\right]_{\mathrm{i}}\right)$ occurs in the early and late stages of apoptosis. The critical characteristic of the apoptotic $\mathrm{Ca}^{2+}$ signal is a sustained, prolong, globalized, and nonoscillatory increase in $\left[\mathrm{Ca}^{2+}\right]_{\mathrm{i}}$, reaching elevated, but not cytotoxic, levels. The mechanism of action of intracellular $\mathrm{Ca}^{2+}$ in apoptotic pathways involves interactions of the cellular $\mathrm{Ca}^{2+}$ signals with $\mathrm{Ca}^{2+}$-dependent molecular targets in cells undergoing apoptosis. The $\mathrm{Ca}^{2+}$-dependent calpains and caspases appear to be the primary $\mathrm{Ca}^{2+}$-activated apoptotic effectors $[7,8,14,29]$.

Specifically, we have shown $[1,2,8-10]$ that a sustained increase in $\left[\mathrm{Ca}^{2+}\right]_{i}$ rapidly signals the cell to enter the apoptotic pathway. The activation of $\mathrm{Ca}^{2+}$-dependent protease $\mu$-calpain followed by the activation of $\mathrm{Ca}^{2+} /$ calpain-dependent caspase- 12 and other effector caspases (e.g., caspase-3) is responsible for the execution of $\mathrm{Ca}^{2+}$-mediated apoptosis. A lack of expression or low levels of cytosolic $\mathrm{Ca}^{2+}$ binding proteins (e.g., vitamin D-dependent calbindins) decrease $\mathrm{Ca}^{2+}$-buffering capacity of the cell, resulting in $\left[\mathrm{Ca}^{2+}\right]_{\mathrm{i}}$ increase and the induction of apoptosis $[32,33]$. We have further shown that $1,25(\mathrm{OH})_{2} \mathrm{D}_{3}$ differentially activates the voltage-dependent and voltage-insensitive $\mathrm{Ca}^{2+}$ entry pathways and differentially triggers $\mathrm{Ca}^{2+}$ release from the endoplasmic reticulum (ER) stores through the inositol 1,4,5-trisphosphate receptor/ $\mathrm{Ca}^{2+}$ release channels $\left(\mathrm{IP}_{3} \mathrm{Rs}\right)$ and ryanodine receptor/ $\mathrm{Ca}^{2+}$ release channels (RYRs) in several cell types $[9,10,12,14,28]$. It appears that $\mathrm{Ca}^{2+}$ signals triggered by $1,25(\mathrm{OH})_{2} \mathrm{D}_{3}$ in different cell types (e.g., transient vs. prolonged or oscillatory vs. sustained, steady $\mathrm{Ca}^{2+}$ fluxes) can be linked to both membrane and nuclear VDRs [8-10]. Remarkably, mature adipocytes demonstrate some of the $\mathrm{Ca}^{2+}$ handling characteristics (the lack of voltage-dependent $\mathrm{Ca}^{2+}$ channels, expression of voltage-insensitive $\mathrm{Ca}^{2+}$ channels, low cytosolic $\mathrm{Ca}^{2+}$ buffering capacity) conducive to the induction of $\mathrm{Ca}^{2+}$-mediated apoptosis with $1,25(\mathrm{OH})_{2} \mathrm{D}_{3}[14-16,33]$.

We have shown that $1,25(\mathrm{OH})_{2} \mathrm{D}_{3}$ induces apoptosis in adipocytes via a mechanism linked to the activation of $\mathrm{Ca}^{2+}$-dependent $\mu$-calpain and $\mathrm{Ca}^{2+} /$ calpain-dependent caspase-12 [14-16]. The treatment of mature adipocytes with $1,25(\mathrm{OH})_{2} \mathrm{D}_{3}$ induced, in a concentration- and time-dependent manner, a sustained increase in $\left[\mathrm{Ca}^{2+}\right]_{\mathrm{i}}$, and this increase led to the execution of apoptosis via activation of $\mu$-calpain and caspase- 12 . The susceptibility of mature adipocytes to the $\mathrm{Ca}^{2+}$-elevating effect of $1,25(\mathrm{OH})_{2} \mathrm{D}_{3}$ appears linked to the low $\mathrm{Ca}^{2+}$-buffering capacity of these cells. These findings demonstrate that $\mathrm{Ca}^{2+}$-mediated apoptosis can be induced in mature adipocytes and that the apoptotic molecular targets activated by $1,25(\mathrm{OH})_{2} \mathrm{D}_{3}$ in these cells are $\mathrm{Ca}^{2+}$-dependent $\mu$-calpain and caspase- 12 .

\section{Vitamin D and Diet-Induced Obesity}

A high-fat-diet-induced obesity (DIO) mouse model is characterized by obese phenotype, increased blood glucose concentration, and development of adiposity $[6,13]$. We have shown that DIO mice fed a diet with high vitamin $\mathrm{D}_{3}$ content demonstrate a decreased weight of adipose tissue and improved biomarkers of adiposity and vitamin D status [38,39]. The glucose and insulin concentrations in the blood of those mice were significantly decreased (to the levels measured in the non-obese control), whereas the concentration of adiponectin (an insulin-sensitizing adipokine) was increased. Moreover, low vitamin D status (a decreased plasma concentration of $25(\mathrm{OH}) \mathrm{D}_{3}$ ) and a decreased concentration of the hormone $1,25(\mathrm{OH})_{2} \mathrm{D}_{3}$ were observed in DIO mice. High vitamin $\mathrm{D}_{3}$ intake was accompanied by a significant increase in plasma concentration of $25(\mathrm{OH}) \mathrm{D}_{3}$ and $1,25(\mathrm{OH})_{2} \mathrm{D}_{3}$ to the levels corresponding to high vitamin D nutritional status and normal vitamin $\mathrm{D}$ hormonal status. High vitamin $\mathrm{D}_{3}$ intake was also associated with the induction of apoptosis (measured by morphological criteria, oligonucleosomal DNA fragmentation and ssDNA breaks) and the activation of $\mathrm{Ca}^{2+}$-dependent apoptotic proteases (calpain and caspase-12) in adipose tissue of DIO mice. Additionally, high vitamin $\mathrm{D}_{3}$ intake increased mineral (Ca and $\mathrm{P}$ ) content in the bone of DIO mice via regulatory effects mediated by the $1,25(\mathrm{OH})_{2} \mathrm{D}_{3}$-parathyroid hormone $(\mathrm{PTH})$ axis (an increase in $1,25(\mathrm{OH})_{2} \mathrm{D}_{3}$ and $\mathrm{Ca}^{2+}$ concentration and a decrease in PTH concentration in blood) [39]. These results demonstrate that high vitamin $\mathrm{D}$ intake can effectively normalize biomarkers related to obesity and that the hormonal mechanism of these effects involves $1,25(\mathrm{OH})_{2} \mathrm{D}_{3}$. The findings also imply that increased vitamin $\mathrm{D}$ intake may contribute to the prevention of obesity and obesity-associated bone disorders. 


\section{Summary}

The studies reviewed here identified the novel $1,25(\mathrm{OH})_{2} \mathrm{D}_{3}$-regulated apoptotic pathway in adipocytes, namely: sustained increase in intracellular $\mathrm{Ca}^{2+} \rightarrow$ activation of $\mathrm{Ca}^{2+}$-dependent calpain $\rightarrow$ activation of $\mathrm{Ca}^{2+} /$ calpain-dependent caspase- $12 \rightarrow$ execution of apoptosis. These studies demonstrated that the $1,25(\mathrm{OH})_{2} \mathrm{D}_{3}$-activated molecular targets executing apoptosis in adipocytes are $\mathrm{Ca}^{2+}$-dependent calpain and $\mathrm{Ca}^{2+} /$ calpain-dependent caspase-12 (Figure 1). Low vitamin D status in obesity and the role of $1,25(\mathrm{OH})_{2} \mathrm{D}_{3}$ in controlling adipose tissue mass in vivo by regulating adipocyte apoptosis may imply a mechanistic role for vitamin $\mathrm{D}$ in adiposity. Preclinical studies and clinical trials will be necessary to confirm the validity of $1,25(\mathrm{OH})_{2} \mathrm{D}_{3}$ - and $\mathrm{Ca}^{2+}$-dependent molecular targets in apoptotic pathways for the prevention and treatment of obesity [40].
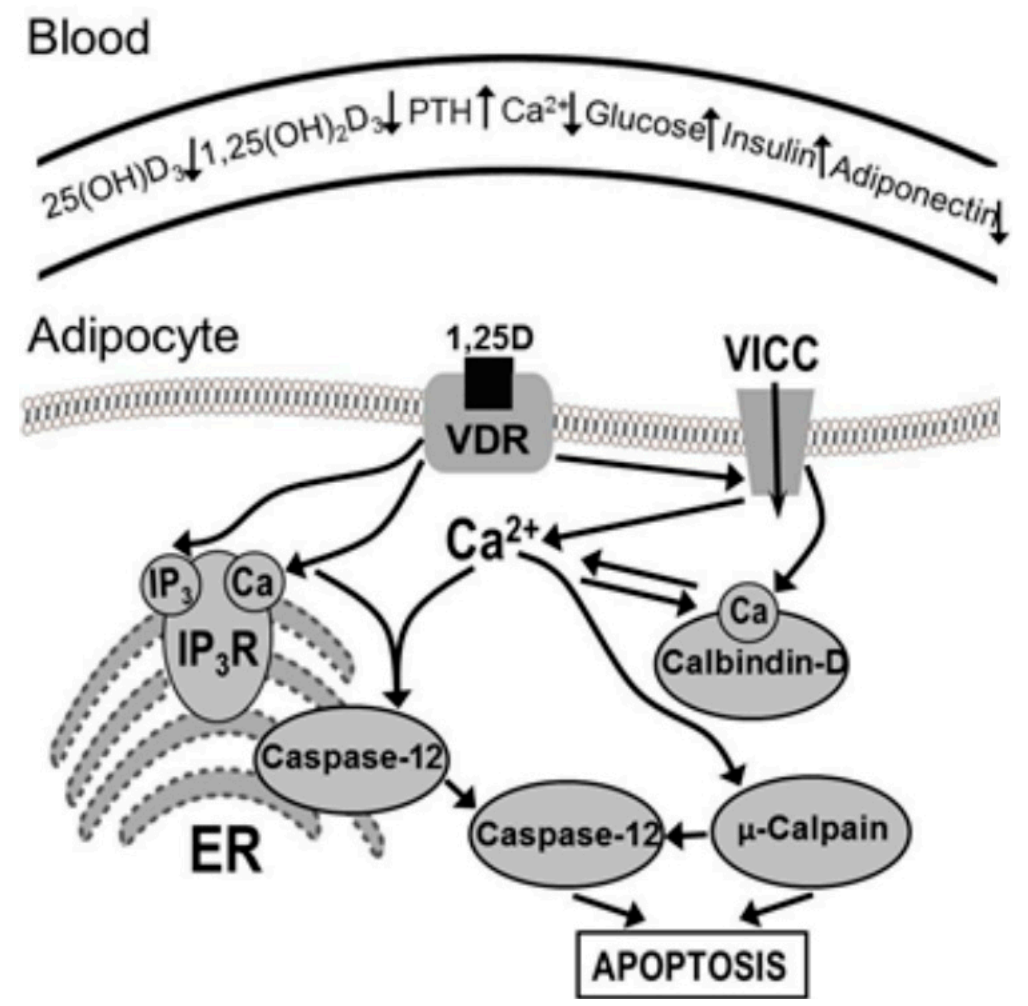

Figure 1. Mechanisms of regulation of intracellular $\mathrm{Ca}^{2+}$ and apoptosis by 1,25 -dihydroxyvitamin $\mathrm{D}_{3}$ $\left(1,25(\mathrm{OH})_{2} \mathrm{D}_{3}\right)$ in obesity. VDR-vitamin D receptor; VICC-voltage-insensitive $\mathrm{Ca}^{2+}$ channels; $\mathrm{IP}_{3} \mathrm{R}$-inositol 1,4,5-trisphosphate receptor/ $\mathrm{Ca}^{2+}$ release channel; ER-endoplasmic reticulum; $\mathrm{PTH}$ - parathyroid hormone. Adapted from reference [2] with permission from Elsevier.

The cartoon provides a schematic representation of the possible mechanism of action of $1,25(\mathrm{OH})_{2} \mathrm{D}_{3}$ in inducing cellular $\mathrm{Ca}^{2+}$ signals and $\mathrm{Ca}^{2+}$-mediated apoptosis in mature adipocytes. Changes in the vitamin D status, $\mathrm{Ca}^{2+}$ regulatory hormones, and obesity-related biomarkers in the blood are also shown. This representation is largely based on the author's studies employing an in vitro model of mature adipocytes and a mouse model of diet-induced obesity (DIO). Briefly, $1,25(\mathrm{OH})_{2} \mathrm{D}_{3}$ regulates $\mathrm{Ca}^{2+}$ entry from the extracellular space, $\mathrm{Ca}^{2+}$ mobilization from the intracellular stores, and intracellular (cytosolic) $\mathrm{Ca}^{2+}$ buffering. Moreover, $1,25(\mathrm{OH})_{2} \mathrm{D}_{3}$ induces $\mathrm{Ca}^{2+}$ influx from the extracellular space and $\mathrm{Ca}^{2+}$ mobilization from the endoplasmic reticulum (ER) stores via the high permeability voltage-insensitive $\mathrm{Ca}^{2+}$ channels (VICC) and $\mathrm{IP}_{3}$ receptor/ $/ \mathrm{Ca}^{2+}$ release channel $\left(\mathrm{IP}_{3} \mathrm{R}\right)$, respectively. Vitamin $\mathrm{D}$ receptors (VDRs) are expressed in adipocytes, and they can be found associated with the cell membrane as well as in the nuclear and cytosolic compartments. Vitamin D-dependent $\mathrm{Ca}^{2+}$ buffering calbindin- $\mathrm{D}_{9 \mathrm{k}}$ appears to be expressed at a low level in mature 
adipocytes, which contributes to a decreased $\mathrm{Ca}^{2+}$ buffering capacity of these cells. $1,25(\mathrm{OH})_{2} \mathrm{D}_{3}$ activates the calpain/caspase-12-dependent apoptotic pathway in adipocytes by inducing the apoptotic $\mathrm{Ca}^{2+}$ signal-a sustained, prolong, globalized, and nonoscillatory increase in $\left[\mathrm{Ca}^{2+}\right]_{\mathrm{i}}$ reaching elevating (200-500 nM), but not cytotoxic $(>1 \mu \mathrm{M})$ levels-via $\mathrm{Ca}^{2+}$ release from the ER stores and $\mathrm{Ca}^{2+}$ entry through the VICC. $\mu$-Calpain activation by the sustained cytosolic $\mathrm{Ca}^{2+}$ signal is followed by activation (i.e., $\mathrm{Ca}^{2+}$-dependent translocation from the $\mathrm{ER}$ membrane to cytosol and calpain-dependent processing/cleavage) of $\mathrm{Ca}^{2+} /$ calpain-dependent caspase-12. Activation of these proteases appears to be sufficient for the execution of apoptosis as evaluated by the hallmarks of this process: apoptotic changes of the plasma membrane (phosphatidylserine translocation from the inner to outer surface of the plasma membrane) and nuclear condensation and DNA fragmentation (oligonucleosomal fragments and ssDNA breaks).

Funding: This research received no external funding.

Acknowledgments: The author's studies reviewed in this article were supported by the National Institutes of Health (1R15CA067317-01A1 and 7R15CA067317-02) and the U.S. Department of Agriculture (SD00179H, SD00294H, SD00H167-061HG, SD00H533, and 2009-35200-05008) grants to I.N.S.

Conflicts of Interest: The author declares no conflict of interest.

\section{References}

1. Sergeev, I.N. 1,25-Dihydroxyvitamin $\mathrm{D}_{3}$ and type 2 diabetes: $\mathrm{Ca}^{2+}$-dependent molecular mechanisms and the role of vitamin D status. Horm. Mol. Biol. Clin. Invest. 2016, 26, 61-65. [CrossRef] [PubMed]

2. Sergeev, I.N. Vitamin D-Cellular $\mathrm{Ca}^{2+}$ link to obesity and diabetes. J. Steroid Biochem. Mol. Biol. 2016, 164, 326-330. [CrossRef] [PubMed]

3. Norman, A.W.; Bouillon, R.; Vitamin, D. nutritional policy needs a vision for the future. Exp. Biol. Med. 2010, 235, 1034-1045. [CrossRef] [PubMed]

4. Sergeev, I.N.; Rhoten, W.B.; Spirichev, V.B.; Vitamin, D. Intracellular calcium. Subcell. Biochem. 1998, 30, 271-297. [PubMed]

5. Norman, A.W.; Nemere, I.; Zhou, J.; Bishop, J.E.; Lowe, K.E.; Maiyar, A.C.; Collins, E.D.; Taoka, T.; Sergeev, I.; Farach-Carson, M.C. 1,25(OH) 2 -Vitamin $\mathrm{D}_{3}$, a steroid hormone that produces biological effects via genomic and nongenomic pathways. J. Steroid Biochem. Mol. Biol. 1992, 41, 231-240. [CrossRef]

6. Christakos, S.; Hewison, M.; Gardner, D.G.; Wagner, C.L.; Sergeev, I.N.; Rutten, E.; Pittas, A.G.; Boland, R.; Ferrucci, L.; Bilke, D.D. Vitamin D: Beyond bone. Ann. N. Y. Acad. Sci. 2013, 1287, 45-58. [CrossRef]

7. Sergeev, I.N. Regulation of apoptosis in adipocytes and breast cancer cells by $1,25(\mathrm{OH})_{2}$-vitamin $\mathrm{D}_{3}$ : A link between metabolic disorders and breast cancer. Horm. Mol. Biol. Clin. Invest. 2013, 14, 99-106.

8. Sergeev, I.N. Vitamin D and cellular $\mathrm{Ca}^{2+}$ signaling in breast cancer. Anticancer Res. 2012, 32, 299-302.

9. Sergeev, I.N. Calcium signaling in cancer and vitamin D. J. Steroid Biochem. Mol. Biol. 2005, 97, 145-151. [CrossRef]

10. Sergeev, I.N. Calcium as a mediator of 1,25-Dihydroxyvitamin $D_{3}$-induced apoptosis. J. Steroid Biochem. Mol. Biol. 2004, 89-90, 419-425. [CrossRef]

11. Orrenius, S.; Zhivotovsky, B.; Nicotera, P. Regulation of cell death: the calcium-apoptosis link. Nat. Rev. Mol. Cell Biol. 2003, 4, 552-565. [CrossRef] [PubMed]

12. Mathiasen, I.S.; Sergeev, I.N.; Bastholm, L.; Elling, F.; Norman, A.W.; Jaattela, M. Calcium and calpain as key mediators of apoptosis-like death induced by vitamin D compounds in breast cancer cells. J. Biol. Chem. 2002, 277, 30738-30745. [CrossRef] [PubMed]

13. Song, Q.; Sergeev, I.N. Calcium and vitamin D in obesity. Nutr. Res. Rev. 2012, 25, 130-141. [CrossRef] [PubMed]

14. Sergeev, I.N. 1,25-Dihydroxyvitamin $\mathrm{D}_{3}$ induces $\mathrm{Ca}^{2+}$-mediated apoptosis in adipocytes via activation of calpain and caspase-12. Biochem. Biophys. Res. Commun. 2009, 384, 18-21. [CrossRef] [PubMed]

15. Sergeev, I.N. Vitamin D/calcium-mediated apoptosis in cancer cells and adipocytes. FASEB J. 2010, 24, 917-1016.

16. Sergeev, I.N. Vitamin D regulates apoptosis in adipocytes via $\mathrm{Ca}^{2+}$ signaling. FASEB J. 2012, 26, 386-392. 
17. Institute of Medicine. Dietary Reference Intakes for Calcium and Vitamin D; The National Academies Press: Washington, DC, USA, 2011.

18. Ross, A.C.; Manson, J.E.; Abrams, S.A.; Aloia, J.F.; Brannon, P.M.; Clinton, S.K.; Durazo-Arvizu, R.A.; Gallagher, J.C.; Gallo, R.L.; Jones, G.; et al. The 2011 report on dietary reference intakes for calcium and vitamin D from the Institute of Medicine: what clinicians need to know. J. Clin. Endocrinol. Metab. 2011, 96, 53-58. [CrossRef]

19. Holick, M.F.; Binkley, N.C.; Bischoff-Ferrari, H.A.; Gordon, C.M.; Hanley, D.A.; Heaney, R.P.; Murad, M.H.; Weaver, C.M. Evaluation, treatment, and prevention of vitamin D deficiency: An Endocrine Society clinical practice guideline. J. Clin. Endocrinol. Metab. 2011, 96, 1911-1930. [CrossRef]

20. European Food Safety Authority. Scientific opinion on the tolerable upper intake level of vitamin D. EFSA panel on dietetic products, nutrition and allergies (NDA). In EFSA J.; 2012; 10, p. 2813.

21. Spirichev, V.B.; Sergeev, I.N. Vitamin D: Experimental research and its practical application. World Rev. Nutr. Diet. 1988, 56, 173-216.

22. Lamberg-Allardt, C.; Brustad, M.; Meyer, H.E.; Steingrimsdottir, L. Vitamin D-A systematic literature review for the 5th edition of the Nordic Nutrition Recommendations. Food Nutr. Res. 2013, 57, 22671. [CrossRef]

23. Bischoff-Ferrari, H.A. Optimal serum 25-hydroxyvitamin D levels for multiple health outcomes. Adv. Exp. Med. Biol. 2014, 810, 500-525. [PubMed]

24. Murayama, A.; Takeyama, K.; Kitanaka, S.; Kodera, Y.; Kawaguchi, Y.; Hosoya, T.; Kato, S. Positive and negative regulations of the renal 25-hydroxyvitamin $\mathrm{D}_{3} 1 \alpha$-hydroxylase gene by parathyroid hormone, calcitonin, and $1 \alpha, 25(\mathrm{OH})_{2} \mathrm{D}_{3}$ in intact animals. Endocrinology 1999, 140, 2224-2231. [CrossRef] [PubMed]

25. Sergeev, I.N.; Arkhapchev, Y.P.; Spirichev, V.B. Ascorbic acid effects on vitamin D metabolism and binding in guinea pigs. J. Nutr. 1990, 120, 1185-1190. [CrossRef] [PubMed]

26. Norman, A.W.; Sergeev, I.N.; Bishop, J.E.; Okamura, W.H. Selective biological response by target organs (intestine, kidney and bone) to 1,25-dihydroxyvitamin $\mathrm{D}_{3}$ and two analogs. Cancer Res. 1993, 53, 3935-3942.

27. Farach-Carson, M.C.; Sergeev, I.N.; Norman, A.W. Nongenomic actions of 1,25-dihydroxyvitamin $\mathrm{D}_{3}$ in rat osteosarcoma cells: Structure-function studies using ligand analogs. Endocrinology 1991, 129, 1876-1884. [CrossRef]

28. Sergeev, I.N.; Rhoten, W.B. 1,25-Dihydroxyvitamin $\mathrm{D}_{3}$ evokes oscillations of intracellular calcium in a pancreatic $\beta$-cell line. Endocrinology 1995, 136, 2852-2861. [CrossRef]

29. Sergeev, I.N. Genistein induces $\mathrm{Ca}^{2+}$-mediated, calpain/caspase-12-dependent apoptosis in breast cancer cells. Biochem. Biophys. Res. Commun. 2004, 321, 462-467. [CrossRef]

30. Sergeev, I.N.; Norman, A.W. Calcium as a mediator of apoptosis in bovine oocytes and preimplantation embryos. Endocrine 2003, 22, 169-175. [CrossRef]

31. Carafoli, E.; Santella, L.; Branca, D.; Brini, M. Generation, control, and processing of cellular calcium signals. Crit. Rev. Biochem. Mol. Biol. 2001, 36, 107-260. [CrossRef]

32. Sergeev, I.N.; Rhoten, W.B.; Carney, M.D. Calbindins decreased after space flight. Endocrine 1996, 5, 335-340. [CrossRef]

33. Rhoten, W.B.; Sergeev, I.N. Calbindin- $D_{28 k}$ appears to buffer intracellular $\mathrm{Ca}^{2+}$ in butyrate-treated rat insulinoma cells. Endocrine 1994, 2, 989-995.

34. Sergeev, I.N.; Li, S.; Colby, J.; Ho, C.-T.; Dushenkov, S. Polymethoxylated flavones induce Ca ${ }^{2+}$-mediated apoptosis in breast cancer cells. Life Sci. 2006, 80, 245-253. [CrossRef] [PubMed]

35. Sergeev, I.N.; Ho, C.-T.; Lee, S.; Colby, J.; Dushenkov, S. Apoptosis-inducing activity of hydroxylated polymethoxyflavones and polymethoxyflavones from orange peel in human breast cancer cells. Mol. Nutr. Food Res. 2007, 51, 1478-1484. [CrossRef] [PubMed]

36. Sergeev, I.N.; Li, S.; Ho, C.-T.; Rawson, N.E.; Dushenkov, S. Polymethoxyflavones activate $\mathrm{Ca}^{2+}$-dependent apoptotic targets in adipocytes. J. Agric. Food Chem. 2009, 57, 5771-5776. [CrossRef] [PubMed]

37. Sergeev, I.N. Vitamin D-mediated apoptosis in cancer and obesity. Horm Mol. Biol. Clin. Invest. 2014, 20, 43-49. [CrossRef] [PubMed]

38. Sergeev, I.N.; Song, Q. High vitamin D and calcium intakes reduce diet-induced obesity in mice by increasing adipose tissue apoptosis. Mol. Nutr. Food Res. 2014, 58, 1342-1348. [CrossRef] 
39. Song, Q.; Sergeev, I.N. High vitamin D and calcium intakes increase bone mineral (Ca and P) content in high-fat diet-induced obese mice. Nutr. Res. 2015, 35, 146-154. [CrossRef]

40. Sergeev, I.N.; Aljutaily, T.; Walton, G.; Huarte, E. Effects of synbiotic supplement on human gut microbiota, body composition and weight loss in obesity. Nutrients 2020, 12, 222. [CrossRef]

(C) 2020 by the author. Licensee MDPI, Basel, Switzerland. This article is an open access article distributed under the terms and conditions of the Creative Commons Attribution (CC BY) license (http://creativecommons.org/licenses/by/4.0/). 